\title{
Influence of field slope on manual harvesting indicators on citrus in the agricultural sector in Caldas-Colombia
}

INGENIERÍA INDUSTRIAL

\section{Influencia de la pendiente del terreno en los indicadores de cosecha manual de cítricos en el sector agrícola en Caldas- Colombia}

\author{
Alex M. Ovalle-Castiblanco ${ }^{1 \S(\mathbb{D})}$, Diana M. Cárdenas-Aguirre ${ }^{2}$, Cristian F. Jiménez- \\ Varón ${ }^{3}$, Camilo A. Abendaño-Beltrán1(i) \\ ${ }^{1}$ Universidad Autónoma de Manizales, Departamento de Mecánica y Producción, Manizales, Colombia \\ ${ }^{2}$ Universidad Nacional de Colombia-Sede Manizales, Departamento de Ingeniería Industrial, \\ Manizales, Colombia \\ ${ }^{3}$ Universidad Autónoma de Manizales, Departamento de Física y Matemática, Manizales, Colombia \\ \$movalle@autonoma.edu.co,dmcardenasa@unal.edu.co,cristian.jimenezv@autonoma.edu.co, \\ camilo.abendanob@autonoma.edu.co
}

Recibido: 9 de febrero de 2021 - Aceptado: 26 de mayo de 2021

\begin{abstract}
In Colombia the agricultural sector has difficulties in the integration of technologies, due to the difficulties of the topography, very characteristic in the area of Colombian mountain ranges that pass through the main agricultural departments of the country and the limitations of human capacity; the citrus harvesting process has traditionally been done by hand, employing thousands of people who do not achieve significant yields; , thus causing an increase in production costs with an impact on harvest indicators, measured in terms of quality and productivity. This study aims to determine the impact of field slope conditions on quality indicators and indicators of effectiveness, efficiency, and loss indictors, used to evaluate the productivity of the orange harvesting process in a case study in the Department of Caldas-Colombia in order to identify opportunities for process improvement. Field information was made on orangeproducing farms with different land slopes classified into four categories. Statistically significant partnerships were identified between the efficiency, efficiency and loss indicators and the field slope conditions. In addition, some of these indicators showed inverse relationships to the slope gradient. On the contrary, the quality of the fruit is not affected by the slope conditions of the land.
\end{abstract}

Keywords: field slope, harvest indicators, picking process, productivity. 


\section{Resumen}

En Colombia el sector agrícola tiene dificultades en la integración de tecnologías, debido a las dificultades de la topografía, muy característica en la zona de las cordilleras colombianas que pasan por los principales departamentos agrícolas del país y las limitaciones de la capacidad humana ;el proceso de recolección de cítricos se ha hecho tradicionalmente a mano, empleando a miles de personas que no logran rendimientos significativos, provocando así un aumento de los costes de producción con un impacto en los indicadores de cosecha, medidos en términos de calidad y productividad. Este estudio tuvo como objetivo determinar el impacto de las condiciones de la pendiente del terreno en los indicadores de calidad y los indicadores de eficacia, eficiencia y pérdidas, usados para evaluar la productividad del proceso de recolección de naranjas, en un caso de estudio en el Departamento de Caldas-Colombia e identificar así, oportunidades de mejora del proceso. La información sobre el terreno se realizó en fincas productoras de naranja con diferentes pendientes de terreno clasificadas en cuatro categorías. Se logró identificar asociaciones estadísticamente significativas entre los indicadores de eficiencia, eficacia y pérdidas y las condiciones de la pendiente de campo. Además, algunos de estos indicadores mostraron relaciones inversas con el gradiente de pendiente. Por el contrario, la calidad del fruto no se ve afectada por las condiciones de pendiente del terreno.

Palabras clave: indicadores de cosecha, pendiente del terreno, proceso de recolección, productividad.

\section{Introduction}

Fruit consumption is increasing worldwide due to the social and scientific recognition of the nutritional and functional properties of fruits. In the last two decades, global horticultural imports increased their participation among food imports (1). The promotion and development of the fruit sector is an important source of agricultural growth for Colombia, to promote rural employment and equitable development for the different regions ${ }^{(2,3)}$. Given the great diversity of climates and soils, Colombia is a large producer of a wide variety of citrus fruits. This scenario enables exploring new markets and satisfying the demand for citrus fruits in countries that lack suitable climate conditions for this type of crop ${ }^{(4)}$. According to the Food and Agriculture Organization (FAO), in developing countries, most of the products destined for rural and urban markets are harvested by hand. Due to the different stages of fruit ripening and the need for gradual harvesting, an optimized manual harvesting process reduces the probability of product damage compared to mechanized harvesting ${ }^{(5)}$.

One of the greatest topographic difficulties in agriculture is field slope, which refers to the inclination of the land compared to a horizontal plane that passes through its base. It is expressed as a gradient calculated in sexagesimal or centesimal degrees or percentage and, in trigonometric terms, corresponds to the tangent of the angle formed between the decline and its corresponding horizontal (6,7). Several studies focus on the slope of the land and its relationship with agricultural processes. Researchers such as $(8,9)$ agree that soil quality attributes are related topographic properties such as slope position, slope gradient and slope aspects, on the other hand ${ }^{(10)}$, reference the field slope as one of the factors that influences the crops, another aspect attributed to the slope of the land refers to accidentality, the investigation of (11) on the harvest and felling of trees indicating that the risk of suffering an accident increases with the slope of the land.

In the context of the effect of the slope of the land on the use of agricultural machinery are the works carried out by (12) which compared tree harvesting systems by analyzing the productivity of two winch procedures and the influence of soil conditions. One of the procedures was analyzed on flat ground and the other on steep ground. The authors reported significant differences in wind speed of cut trees caused by slope conditions, ${ }^{(13)}$ they determined or the effect of terrain slope on the productivity, cycle time, and elementary times 
of a Valmet 450 FXL self-leveling processor that processes a pine plantation. In contrast to previous research, no significant differences were found between processor productivity, Cycle time and elementary times (movement/positioning, balancing and processing) between slope classes, (14) presents an Integrated Forest Information System (FIS) for optimizing forest production in mountainous areas, Finally, ${ }^{(15)}$ evaluated the operational performance and efficiency of a coffee harvester on a steep slope under different situations and speed fluctuations, finding that the field slope influences the performance of the machine.

In Colombia, the harvesting process greatly depends on manual labor, which affects harvest yield due to different factors, including the topography, the lack of uniformity in fruit ripening, tree height, and the absence of new technologies ${ }^{(16) .}$ The agricultural sector displays a limited integration of technologies, which leads to increased production costs that affect harvest indicators, such as quality and productivity $(17,18)$.

According to the National Administrative Statistics Department (DANE, for its acronyms in Spanish) of Colombia, Caldas holds fifth place in orange fruit production nationwide (19). Consequently, the cultivation of citrus is one of the priorities for the department to strengthen the competitiveness of the region. This requires developing more productive and sustainable agricultural systems to meet the growing demand for food. According to (20), mechanization is crucial for transforming agricultural systems and improving productivity, but as stated above, topographical conditions make it difficult to apply.
This study aimed to determine whether there is an influence between ground slope conditions and indicators of quality, losses, efficiency, and effectiveness measured during manual citrus harvesting.

\section{Methodology}

\subsection{Characteristics of the terrain area}

For the choice of the farms studied, a nonprobabilistic sampling was carried out for convenience in which farms that are in the range greater than 20 hectares cultivated in citrus fruits and that meet the following criteria of inclusion were selected:

- Meet the characteristics of owning terrain ranging from plain to slope greater than 76 degrees of inclination.

- Possess Valencia orange planting.

- Extension of planting of valence orange greater than 100 hectares.

- Express your desire to belong to research and collaborate with access to information.

The different field slopes were classified into four categories, according to the percentage and degree of inclination, as shown in (Table 1).

\subsection{Harvesting indicators}

As in agricultural operations where manual harvesting processes are presented, the variables involved in the operation are affected by climatic conditions, land, experience, and method of collection among others, as expressed by (21) "an excellent collection reconciles the indicators of quality, efficiency, efficiency and losses, and allows an optimization of the resources used in the process". the harvest indicators are described in (Table 2). 
Table 1. Classification of the field slopes in this study

\begin{tabular}{|c|c|c|}
\hline \multirow{2}{*}{$\begin{array}{c}\text { Factor } \\
\text { Slope condition }\end{array}$} & \multicolumn{2}{|c|}{ Slope } \\
\hline & Percentage & Degrees \\
\hline Nearly level to gently sloping & $0-15$ & $0^{\circ}-8.4^{\circ}$ \\
\hline $\begin{array}{l}\text { Moderated to strongly } \\
\text { sloping }\end{array}$ & $16-50$ & $8.5^{\circ}-24.6^{\circ}$ \\
\hline Steep & $51-75$ & $24.7^{\circ}-36.8^{\circ}$ \\
\hline Very steep & $>76$ & $>36.9^{\circ}$ \\
\hline
\end{tabular}

Table 2. Harvesting indicator

\begin{tabular}{ll}
\hline Harvesting Indicator & \multicolumn{1}{c}{ Harvesting measurement } \\
\hline Efficiency & Number of baskets/Working day (baskets =23.4 kg of fruits) \\
Effectiveness & Number of oranges left on the tree/Working day \\
Quality & Percentage of fruits classified: Big-medium-small-stained/baskets \\
Losses & Number of fruits falling on the ground while harvesting a tree
\end{tabular}

Source: adapted from Velez et. al $^{(2 I)}$

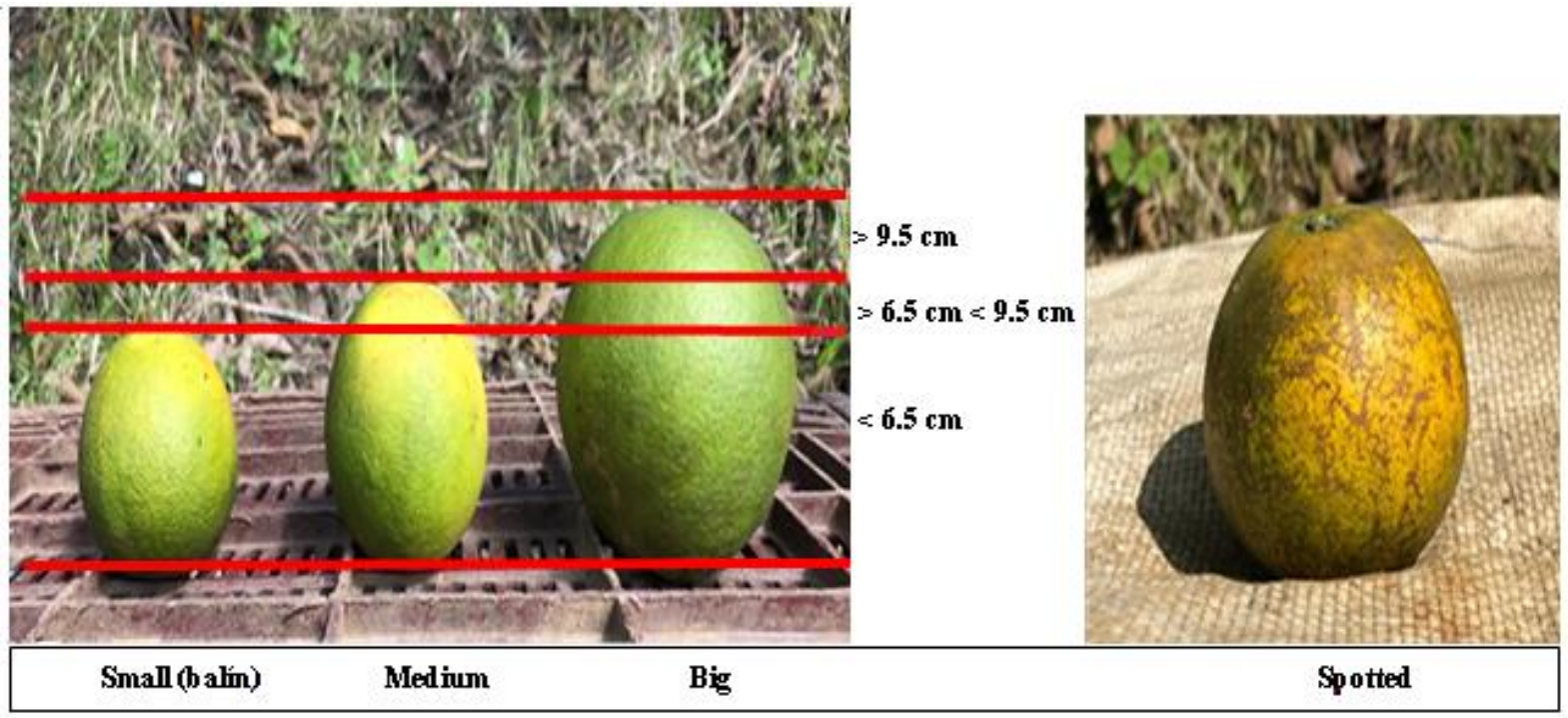

Figure 1. Classification of Valencia orange fruits based on quality. Source: own elaboration

The quality indicator was assessed based on the number of large, medium, small (i.e., "balín" fruits), and spotted Valencia orange fruits harvested in each slope condition. We estimated fruit quality based on the diametric range groups illustrated in (Figure 1), except for spotted oranges, which were found in the three size groups. The qualification of spotted fruit was assigned by the harvester and was based on the presence of spots that exceed approximately $20 \%$ of the fruit surface area.

We sorted and counted the number of oranges in the baskets, which were randomly selected at intervals of 12 minutes in the low season and 6 minutes in the high season (i.e. 5 baskets per harvester per hour/working day in low season and 
10 baskets per harvester per hour/working day in high season). Additionally, we recorded the weight of the fruits to determine the average weight, the amount in kilograms $(\mathrm{Kg})$ collected, and the percentage share of each Valencia orange quality group.

\subsection{Statistical analysis}

We performed an analysis of variance (ANOVA) to establish if the slope condition significantly affects harvest efficiency, effectiveness, and losses. Our null hypothesis was that there is no effect of slope condition on the harvest indicators. First, we evaluated the assumptions of normality, homogeneity of variance, and randomness of the indicators to determine the adequate statistical tests for our analyses (e.g. parametric or nonparametric). We found three indicators that did not adjust to the assumptions of normality and homogeneity of variances, so we performed a non-parametric analysis of Kruskal-Wallis $\mathrm{H}$ variance.For the non-parametric Kruskal-Wallis $\mathrm{H}$ test, we compared the median values of each indicator in the four slope conditions, according to the following hypotheses:

Ho: The medians of the variables are the same or show no significant differences $(\mathrm{Me} 1=\mathrm{Me} 2=$ Me3 = Me4); therefore, there is no relationship between the variable slope condition and the harvest indicator.

$\mathrm{Ha}$ : The medians of the variables are not equal and there are significant differences $(\mathrm{Me} 1 \neq \mathrm{Me} 2$ $\neq \mathrm{Me} 3 \neq \mathrm{Me} 4)$; therefore, there is a relationship between the variable slope condition and the harvest indicator.

When the null hypothesis was rejected for the non-parametric ANOVA, we performed a MannWhitney $U$ test to determine which indicators showed significant differences between slopes. For this, we compared pairwise medians considering the following hypotheses:
Ho: The pairwise medians are the same or show no significant differences (Me1=Me2).

$H a$ : The pairwise medians are not equal and there are significant differences $(\mathrm{Me} 1 \neq \mathrm{Me} 2)$.

Finally, the results are graphically analyzed through box-and-whisker plots to determine the differences between the slope conditions.

\section{Results}

We found significant differences for indicators of harvest efficiency, effectiveness, and losses between slope conditions, demonstrating an effect of the topography (i.e. field slope) on the manual harvesting process.

\subsection{Quality indicators}

We determined that the average weight of a harvested fruit basket is $23.5 \mathrm{~kg}$, of which $14.8 \mathrm{~kg}$ correspond to large oranges (62.9\%), $5.16 \mathrm{~kg}$ to medium-size oranges $(21.9 \%), 1.18 \mathrm{~kg}$ to small or balín oranges $(5.01 \%)$, and $2.36 \mathrm{~kg}$ to spotted oranges $(10.1 \%)$. The results obtained for the quality indicators at each slope condition are shown in (Table 3). We found no significant differences in quality values between slope conditions; therefore, we infer that the quality indicators are not affected by the slope conditions of the crop field.

Regarding the high season, we found statistical differences for all pairwise comparisons between slope conditions (Table 5). Our results indicate that the number of baskets collected per working day during high season is influenced by field slope conditions, mainly steep and very steep slopes.

Similar to our findings for the low season, the box and whisker diagram (Figure 3), shows differences in variability ranges between slopes. We also observed an inverse relationship between the efficiency indicator and the field slope condition; therefore, the number of baskets collected is greater when the angle of inclination of the terrain is lower. Likewise, the lack of 
Table 3. Average weight of oranges per basket for each slope condition according to quality indicators.

\begin{tabular}{|c|c|c|c|c|c|}
\hline \multirow[b]{2}{*}{ Slope condition } & \multicolumn{4}{|c|}{ Quality indicator average per basket $(\mathrm{Kg})$} & \multirow[b]{2}{*}{$\begin{array}{c}\text { Average } \\
\text { Weight }(\mathrm{Kg})\end{array}$} \\
\hline & $\begin{array}{l}\text { Big } \\
(\mathbf{K g})\end{array}$ & $\begin{array}{l}\text { Medium } \\
(\mathrm{Kg})\end{array}$ & $\begin{array}{c}\text { Small (Balín) } \\
\text { (Kg) }\end{array}$ & $\begin{array}{l}\text { Stained } \\
(\mathbf{K g})\end{array}$ & \\
\hline $\begin{array}{l}\text { Nearly level to gently } \\
\text { sloping }\end{array}$ & 15.01 & 5.22 & 1.15 & 2.36 & 23.74 \\
\hline $\begin{array}{l}\text { Moderated and strongly } \\
\text { sloping }\end{array}$ & 14.59 & 5.25 & 1.21 & 2.32 & 23.37 \\
\hline Steep & 14.96 & 5.21 & 1.18 & 2.37 & 23.73 \\
\hline Very steep & 14.62 & 4.97 & 1.19 & 2.41 & 23.19 \\
\hline Total average $(\mathrm{kg})$ & 14.80 & 5.16 & 1.18 & 2.36 & 23.51 \\
\hline Total average $(\%)$ & 62.9 & 21.9 & 5.01 & 10.19 & 23.5 \\
\hline
\end{tabular}

Source: own elaboration

Table 4. Mann-Whitney u-test for effect of slope on efficiency indicators in low season.

\begin{tabular}{lccccc}
\hline Condition1-Condition 2 & Test Statistic & Error & $\begin{array}{c}\text { Test Statistic } \\
\text { Desviation }\end{array}$ & Significance & $\begin{array}{c}\text { Adjusted } \\
\text { Significance }\end{array}$ \\
\hline $\begin{array}{l}\text { Very steep-Steep } \\
\begin{array}{l}\text { Very steep- Moderate to } \\
\text { strongly sloping }\end{array}\end{array}$ & 39.49 & 11.566 & 3.414 & 0.001 & 0.004 \\
$\begin{array}{l}\text { Very steep- Nearly level to } \\
\text { gently sloping }\end{array}$ & 111.13 & 11.566 & 9.508 & 0 & 0 \\
$\begin{array}{l}\text { Steep- Moderate to } \\
\text { strongly sloping }\end{array}$ & 41.01 & 11.566 & 3.546 & 0 & 0 \\
$\begin{array}{l}\text { Steep- Nearly level to } \\
\text { gently sloping }\end{array}$ & 71.64 & 11.566 & 6.194 & 0 & 0.002 \\
$\begin{array}{l}\text { Nearly level to gently } \\
\text { sloping-Moderate to } \\
\text { strongly sloping }\end{array}$ & 30.63 & 11.566 & 2.648 & 0.008 & 0.49 \\
\hline
\end{tabular}

Source: own elaboration

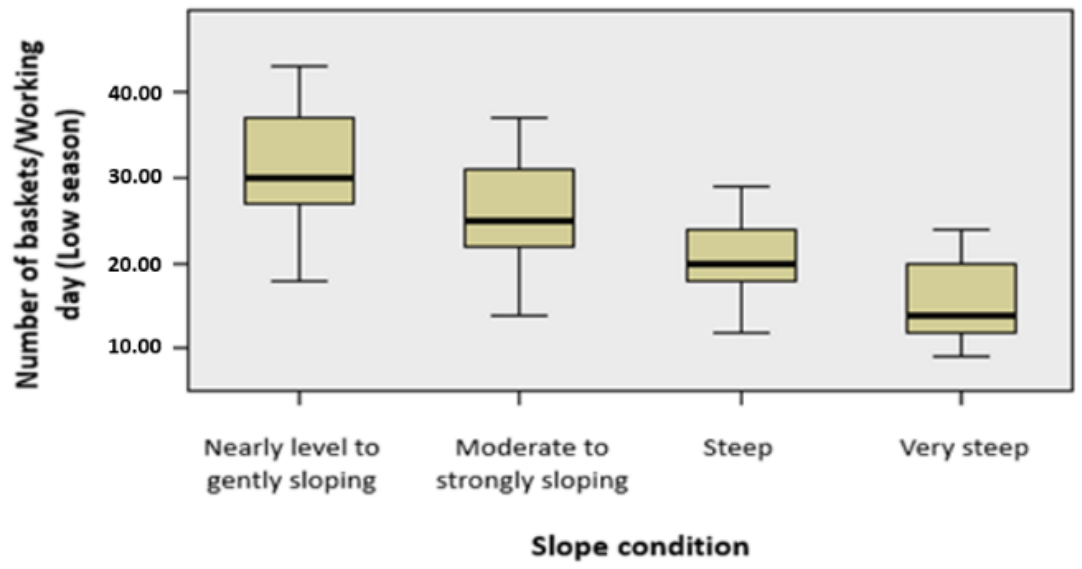

Figure 2. Box and whisker diagram for assessing the influence of slope conditions on efficiency indicators low season. Source: own elaboration 
outliers suggests that the variation in harvest efficiency in each slope condition during high season is under control.

\subsection{Effectiveness indicator}

We found statistically significant differences for effectiveness indicators between the following slope conditions: "nearly level to gently sloping steep", "nearly level to gently sloping - very steep", and "moderate to strongly sloping - very steep", (Table 6).

Furthermore, the number of oranges left on the tree in a working day differed significantly depending on the degree of inclination of the field slope.

The slope conditions showed significant differences regarding the median number of oranges left on the tree/working day, as shown by the box and whisker diagram in (Figure 4). Based on differences in quartile proportionality, we observed that this indicator is most variable under steep and very steep slopes, while nearly level to gently sloping and moderate to strongly sloping conditions show more homogeneity regarding the number of oranges left in the tree.

\subsection{Losses indicator}

We found no statistically significant differences in the number of unrecovered fallen oranges (losses) between "nearly level to gently sloping moderate to strongly sloping" and "steep - very steep" slope conditions (Table 7). These results can be explained by similar degrees of inclination of these slope conditions. Therefore, a greater angle difference between slopes leads to a higher variation in the number of fallen oranges.

Furthermore, the box and whisker diagram (Figure 5) showed significant differences in the variability ranges and quartile proportionality of number of fallen fruits at steep and very steep slopes. Furthermore, the presence of outliers in the number of fallen oranges per working day for a slope condition suggests uncontrolled variation due to special events occurring during manual harvesting.

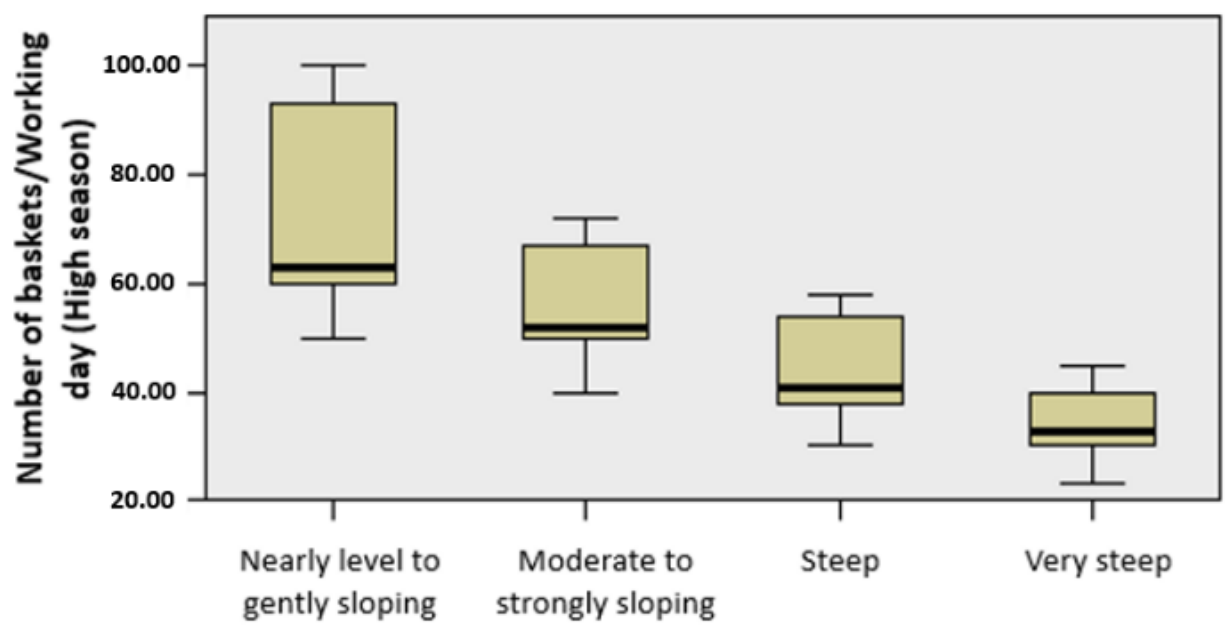

Slope condition

Figure 3. Box and whisker diagram for assessing the influence of slope conditions on efficiency indicators high season. Source: own elaboration 


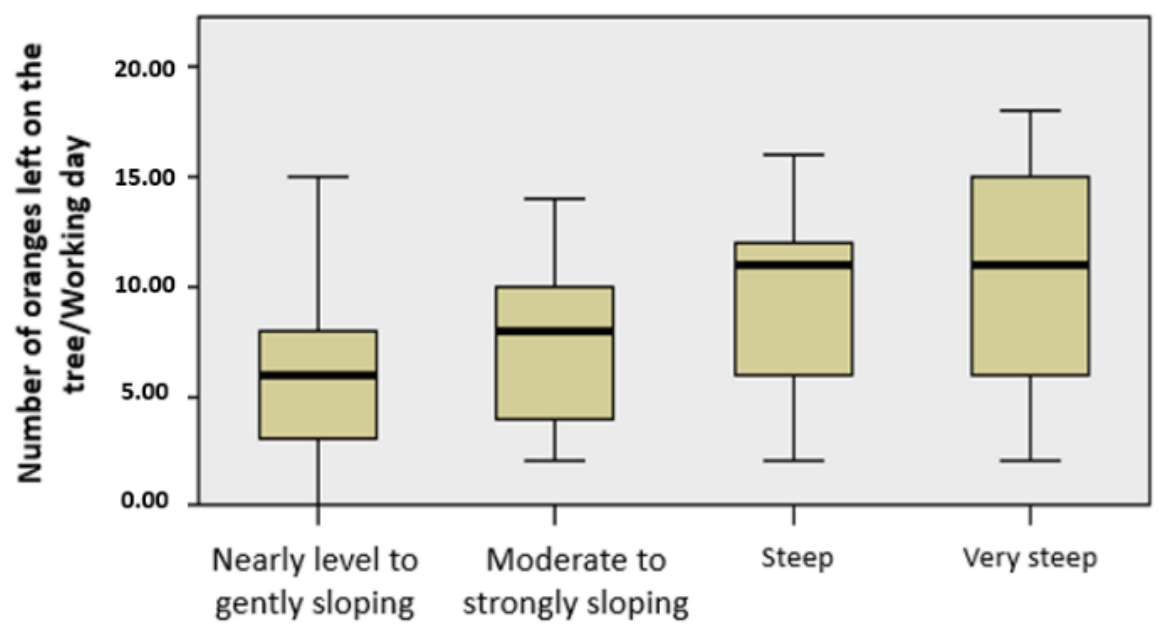

Slope condition

Figure 4. Box and whisker diagram for assessing the influence of slope conditions on effectiveness indicators.

Source: own elaboration

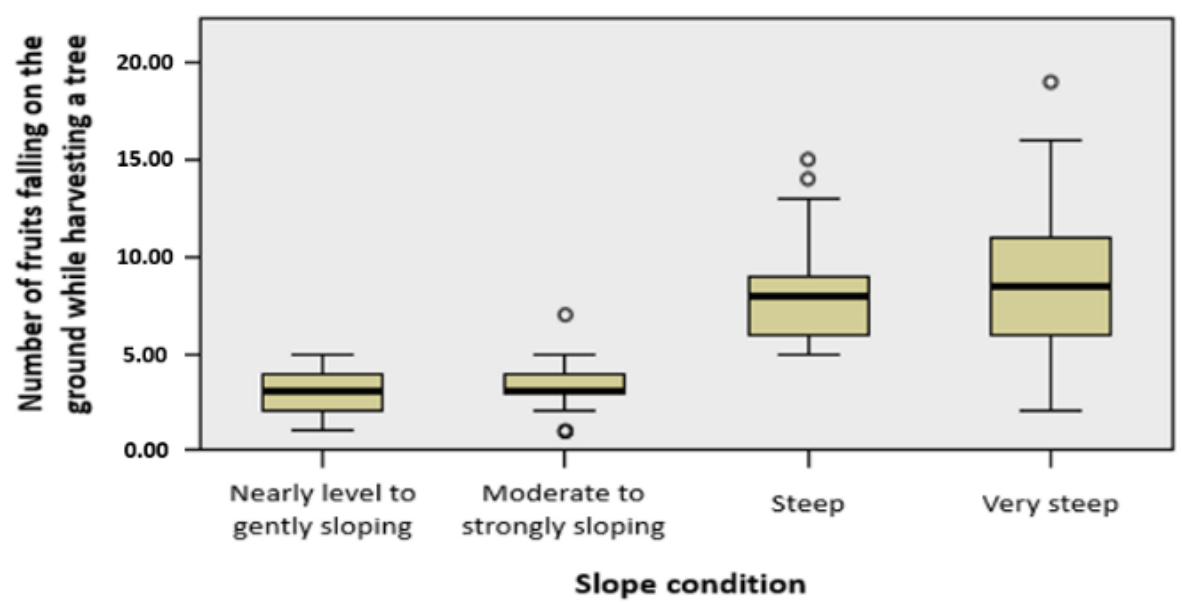

Figure 5. Box and whisker diagram for assessing the influence of slope conditions on losses indicators. Source: own elaboration

Table 5. Mann-Whitney u-test for effect of slope on efficiency indicators in high season.

\begin{tabular}{lccccc}
\hline \multicolumn{1}{c}{ Condition1-Condition 2 } & Test Statistic & Error & $\begin{array}{c}\text { Test Statistic } \\
\text { Desviation }\end{array}$ & Significance & $\begin{array}{c}\text { Adjusted } \\
\text { Significance }\end{array}$ \\
\hline Very steep-Steep & 42.71 & 11.57 & 3.691 & 0 & 0.001 \\
Very steep-Moderate to strongly sloping & 89.18 & 11.57 & 7.708 & 0 & 0 \\
Very steep-Nearly level to gently sloping & 122.67 & 11.57 & 10.602 & 0 & 0 \\
Steep-Moderate to strongly sloping & 46.47 & 11.57 & 4.016 & 0 & 0 \\
Steep - Nearly level to gently sloping & 79.96 & 11.57 & 6.911 & 0 & 0 \\
$\begin{array}{l}\text { Nearly level to gently sloping-Moderate to } \\
\text { strongly sloping }\end{array}$ & 33.49 & 11.57 & 2.895 & 0.004 & 0.023 \\
\hline
\end{tabular}

Source: own elaboration 
Table 6. Mann-Whitney u-test for effect of slope on effectiveness indicators

\begin{tabular}{lccccc}
\hline \multicolumn{1}{c}{ Condition1-Condition 2 } & Test Statistic & Error & $\begin{array}{c}\text { Test Statistic } \\
\text { Desviation }\end{array}$ & Significance & $\begin{array}{c}\text { Adjusted } \\
\text { Significance }\end{array}$ \\
\hline $\begin{array}{l}\text { Nearly level to gently sloping- Moderate to } \\
\text { strongly sloping }\end{array}$ & -18.54 & 11.548 & -1.605 & 0.108 & 0.65 \\
$\begin{array}{l}\text { Nearly level to gently sloping- Steep } \\
\text { Nearly level to gently sloping- Very steep }\end{array}$ & -47.97 & 11.548 & -4.154 & 0 & 0 \\
Moderate to strongly sloping- Steep & -60.17 & 11.548 & -5.21 & 0 & 0 \\
Moderate to strongly sloping- Very steep & -41.63 & 11.548 & -3.605 & 0.011 & 65 \\
Steep -Very steep & -12.2 & 11.548 & -1.056 & 0.291 & 0.002 \\
\hline
\end{tabular}

Source: own elaboration

Table 7. Mann-Whitney u-test for effect of slope on losses indicators.

\begin{tabular}{lccccc}
\hline \multicolumn{1}{c}{ Condition1-Condition 2 } & Test Statistic & Error & $\begin{array}{c}\text { Test Statistic } \\
\text { Desviation }\end{array}$ & Significance & $\begin{array}{c}\text { Adjusted } \\
\text { Significance }\end{array}$ \\
\hline $\begin{array}{l}\text { Nearly level to gently sloping- Moderate to } \\
\text { strongly sloping }\end{array}$ & -11.34 & 11.499 & -0.986 & 0.324 \\
Nearly level to gently sloping- Very Steep & -96.48 & 11.499 & -8.39 & 0 & 0 \\
Nearly level to gently sloping- Steep & -98.74 & 11.499 & -8.587 & 0 & 0 \\
Moderate to strongly sloping- Very steep & -85.14 & 11.499 & -7.404 & 0 & 0 \\
Moderate to strongly sloping- Steep & -87.4 & 11.499 & -7.601 & 0.844 \\
Steep -Very steep & 2.26 & 11.499 & 0.197 & 0
\end{tabular}

Source: own elaboration

\section{Discussion}

Regarding the quality indicator and supported by the results obtained, it is presumed that the quality of the fruit, measured in terms of size and surface appearance, does not present statistical association with the slope conditions of the terrain, the quality depends on external factors, attributed temperature, which as indicated by ${ }^{(22)}$, it must be taken into account that citrus fruits, as well as other tropical and subtropical fruits, present a special sensitivity to low temperatures, which is manifested by different alterations and spots on the skin, known generally as cold injury, cold damage or chilling injury (CI), and which can involve a high loss of commercial quality, moisture, substance or fertilizer used to improve soil quality, fumigation techniques and efficient herbicide management. Like citrus leprosis, as it is known, it is caused primarily by citrus leprosis virus $\mathrm{C}(\mathrm{CiLV}-\mathrm{V})^{(23)}$.

As previously expressed, the harvest seasons were separated into high and low seasons, due to the significant difference that occurs in the average number of fruits collected in basket units per working day. As the slope softens, there is an average increase in the efficiency indicator, finding percentage increases of $32 \%$ when going from the very steep slope to the steep slope, $27 \%$ when moving from the steep slope to the moderated to strongly sloping and $27.5 \%$ of the 
moderated to strongly sloping to the Nearly level to gently sloping, in the high season and the same phenomenon occurs in the low season with percentages of $33 \%, 26 \%$ and $20 \%$ respectively, presenting a greater percentage difference in each inclination in the season with the fewest number of fruits on the tree.

Finally, the effectiveness indicator did not show any significant difference between harvest seasons, since the fruits suitable for harvesting and that are not collected during the day, are due to the location they present in the tree, making it difficult for the collector to reach them with his hands, being necessary in some cases the use of additional elements such as rods with adapted devices to grasp the fruit; On the other hand, the indicator of losses occurs when the collector drops the fruits to the ground, due to the difficulty of holding it when taking them from the tree, this indicator increases when conditions of steep and very steep slope are present, since the shape of the fruit, this rolls and it is not possible to recover it from the areas close to the process. evidently ratifying that slope conditions affect this indicator.

\section{Conclusions}

There is a clear influence of field slope condition on harvest efficiency, effectiveness, and losses, while harvest quality is affected by factors other than the slope of the terrain. By categorizing the field slope in ranges and pairs, we determined statistically significant relationships at extreme slope conditions, such as nearly level to gently sloping and very steep.

As demonstrated by the Mann-Whitney U test, the efficiency indicator is the one that presents the greatest alterations in the terrain with a very steep and extremely steep slope, the slope type factor, allows us to see an inverse relationship, so that the number of baskets collected is greater if the angle of inclination of the terrain is smaller.
Field slope conditions hinder the automation and mechanization of the harvesting process; therefore, determining the impact of field slope on manual harvesting indicators is a promising research topic to improve the productivity of the agricultural sector.

The project did not consider the experience of the collectors, because the ranges of experience calculated in years did not present statistically significant differences, but the authors consider that the experience of the collectors is an important factor that should be considered and analyzed in future research with a larger population sample.

The study of harvesting indicators will help to identify the main factors that are involved in the manual harvesting process of citrus, helping to develop new tools with ergonomic characteristics that allow to improve the yields of the process and contribute to the improvement of the postures that they generate. musculoskeletal injuries to collectors.

\section{Acknowledgements and Funding Statement}

Authors wish to thank Universidad Autónoma de Manizales because received financial support for this research from through the project 483-2016 TD.

\section{References}

(1) Miranda-Lasprilla D. Estado actual de fruticultura colombiana y perspectivas de Desarrollo. Rev. Bras. Frutic. 2011;33(Jaboticabal SP):199-205. https://doi.org/10.1590/S010029452011000500023

(2) MADR, FNFH, ASOHOFRUCOL, SAG. Plan frutícola Nacional - Diagnóstico y análisis de los recursos para la fruticultura 
en Colombia [Internet] 2006 [cited 2019 Nov 25]. Available from: https://repository.agrosavia.co/handle/20.5 $00.12324 / 12401$

(3) Frutas, el nuevo camino exportador. Revista Semana [Internet] 2015 Jun 22 [cited 2019 Dec 12] Available from: https://www.semana.com/pais/articulo/exp ortaciones-colombianas-fruta/209741/

(4) Escobar M. Cadena de los cítricos en Colombia. Manizales: Ministerio de Agricultura y Desarrollo Rural [Internet] 2014 [cited 2020 may 23]. Available from: http://www.citricaldas.com.co/wpcontent/uploads/Cadena-Citricos-ManuelEscobar-Quijano-Sep-24-2014.pdf.

(5) López AF. Manual para la preparación y venta de frutas y hortalizas: del campo al mercado [Internet]. Roma: Boletin de servicios agrícolas de la FAO; 2003 [cited 2020 Feb 12] Available from: http://www.fao.org/3/Y4893S/Y4893S00. htm

(6) FAO. Guía para la descripción de suelos [Internet]. 4th ed. Rome: FAO; 2009. 111 p. Available from: http://www.fao.org/3/a0541s/a0541s.pdf.

(7) Rodriguez E, Sandoval J, Chapparro J, Trejos G, Medina E, et al. Guía metodológica para la zonificación de amenaza por movimientos en masa escala 1:25.000 [Internet]. Bogotá: Servicio Geológico Colombiano; 2017. 217 p. [cited 2020 Jan 28]. Available from: https://www2.sgc.gov.co/Archivos/GM(20 17).pdf

(8) Khormali F, Ajami A, Ayoubi S, Srinivasarao C, Wani S. Role of deforestation and hillslope position on soil quality attributes of loess-derived soils in
Golestan province, Iran. Agric. Ecosyst. Environ.2009;134:178-189.

https://doi.org/10.1016/j.agee.2009.06.017

(9) Wang Y, Zhang XC, Zhang JL, Li SJ. Spatial variability of soil organic carbon in a watershed on the loess plateau. Pedosphere. 2009;19:486-495. https://doi.org/10.1016/S10020160(12)60026-5

(10) Paz-Kagan T, Ohana-Levi N, Herrmann I, Zaady E, Henkin Z, Karnieli A. Grazing intensity effects on soil quality: a spatial analysis of a Mediterranean grassland. Catena. 2016;146:100-110. http://dx.doi.org/10.1016/j.catena.2016.04. 020

(11) Poje A, Potočnik I, Košir B, Krč J. Cutting patterns as a predictor of the odds of accident among professional fellers. Safety science. 2016;89:158-166. https://doi.org/10.1016/j.ssci.2016.06.011

(12) Yoshida M, Sakai H. Winch Harvesting on Flat and Steep Terrain Areas and Improvement of its Methodology. Croat. j. for. Eng. 2015;36(1):55-61. Available from: http://www.crojfe.com/archive/volume36-no-1/winch-harvesting-on-flat-andsteep-terrain-areas-and-improvement-ofits-methodology/

(13) Strandgard M, Alam M, Mitchell R. Impact of Slope on productivity of a self-leveling processor. Croatian Journal of Forestry Engineering. $\quad 2014 ; 35(2): 193-200$. http://www.crojfe.com/archive/volume35-no-2/impact-of-slope-on-productivityof-a-self-levelling-processor/

(14) Panizzoni G, Magliocchetti D, Prandi F, De Amicis R. Interactive virtual planning tools 
for sustainable forest production in mountainous areas. In: Stephanidis C. eds. HCI International 2015 - Posters' Extended Abstracts. HCI 2015. Communications in Computer Science and Information Sciences, vol 528. Springer, Cham. https://doi.org/10.1007/978-3-319-213804_39.

(15) Santinato F, Pereira R, De Albulquerque V, Da Silva C, De Olivera T. Mechanical harvesting of coffee in high slope. Catinga. 2016;29(3):685-691. https://doi.org/10.1590/1983-

21252016v29n319rc

(16) Cadena G. Engineering and Agro. Revista de Ingeniería. 2011;33:70-87. https://doi.org/10.16924/revinge.33.8

(17) Oliveros C, Sanz J. Ingeniería y café en Colombia. Revista de Ingeniería.2011. 33:99-114.

https://doi.org/10.16924/revinge.33.10.

(18) Cortes E, Alvarez F, Gonzalez H. La mecanización agrícola: gestión, selección y administración de la maquinaria para las operaciones de campo. Revista CES Medicina y Veterinaría. 2009;4(2):151160.

(19) DANE. El cultivo de la naranja Valencia (Citrus sinensis [L.] Osbeck) y su producción como respuesta a la aplicación de correctivos y fertilizantes y al efecto de la polinización dirigida con abeja Apis mellifera [Internet]. DANE. 2016. [cited 2020 Apr 24] Boletín mensual, no.52. Available from: https://www.dane.gov.co/files/investigacio nes/agropecuario/sipsa/Bol_Insumos_oct_ 2016.pdf.
(20) FAO. The State of Food and Agriculture 2017. Leveraging food systems for inclusive rural transformation [Internet]. FAO. 2017 [cited 2020 Dec 12] Available from: http://www.fao.org/policysupport/resources/resourcesdetails/en/c/1046886/

(21) Vélez J, Montoya E, Oliveros C. Estudio de Tiempos y Movimientos para la Cosecha Manual de Café [Internet]. Chinchiná: CENICAFÉ. 1999. [cited 2020 Nov 13]. Boletín Técnico No. 21. Available from: http://hdl.handle.net/10778/593

(22) Carvalho CPP, Navarro P, Salvador A. Poscosecha. In: Cítricos: Cultivo, Poscosecha e Industrialización [Internet]. 1st ed. Caldas: Corporación Universitaria Lasallista; 2012. p. 233-84. Available from:

https://studylib.es/doc/7697405/c\%C3\%A Dtricos--cultivo--poscosecha-eindustrializaci\% $\mathrm{C} 3 \% \mathrm{~B} 3 \mathrm{n}$

(23) León G, Roy A, Choudhary N, Brlansky R. Transmisión de leprosis de los cítricos por ácaros Brevipalpus yothersi a través de hospederos no cítricos. Corpoica Cienc Tecnol Agropecuaria. 2017;18(2):307-319. http://dx.doi.org/10.21930/rcta.vol18_num 2_art:633 